\title{
Residual Effects of Chemical Fertilizers, Organic Manure and Biofertilizers Applied to Preceding Gobhi sarson Crop on Summer Mung Bean (Vigna radiata L.)
}

Rekha Ratanoo, S.S. Walia, K.S. Saini, G.S. Dheri

10.18805/LR-4767

\begin{abstract}
Background: Inclusion of legume crops in multiple cropping systems has become crucial to increase the sustainability of agroecosystems. Short duration mung bean can be easily fitted into many cropping sequences which also turns the farming highly remunerative along with strengthening the sustainability. The current study was aimed to evaluate residual effect of nutrient management on performance of summer mung bean in a gobhi sarson - summer mung bean sequence.

Methods: During the period of 2016-17 and 2017-18 different doses of chemical fertilizers (NPK), combination of FYM with chemical fertilizers and different biofertilizers alone as well as their combination were evaluated to find out their residual effect on summer mung bean grown after the gobhi sarson crop. The data on growth parameters, yield attributes viz; plant height, dry matter accumulation, number of branches per plant, number of pods per plant, number of seeds per pod, 100- seed weight were collected. The seed and biological yield from different treatments was also evaluated.

Result: All growth parameters, yield attributes, seed and biological yield of summer mung bean were affected significantly with chemical fertilizers, their combined application with FYM treatments as well as different biofertilizers treatments applied to preceding gobhi sarson. Growth and yield significantly improved with each incremental dose of chemical fertilizers i.e. from 0 to $50 \%$ RDF, 50 to $75 \%$ RDF, 75 to $100 \%$ RDF while 50\% RDF + FYM @ $10 \mathrm{t} \mathrm{ha}^{-1}$ being the best treatment. The treatment with consortium showed significantly maximum yield and growth parameters followed by combined application of Azotobacter + PSB, PSB alone, Azotobacter alone and no inoculation treatments, respectively.
\end{abstract}

Key words: Biofertilizers, Chemical fertilizers, Consortium, Residual effect FYM, Summer mung bean.

\section{INTRODUCTION}

Sustainability of cereal-cereal cropping systems, most prevalent over entire south-east Asia after the advent of green revolution, has been questioned since last two and a half decade due to the depletion of soil fertility and many more reasons (Jat et al., 2016). Consequently, inclusion of many alternative crops in the cropping systems has been evaluated and suggestions were made on the basis of those by several researchers. Summer mungbean fits well in many crop sequences owing to availability of short duration varieties, low input requirements and most importantly its leguminous characteristics of increasing the soil fertility.

In Punjab, gobhi sarson-summer mung bean sequence for winter and spring season is one of the recommended alternatives of rice-wheat cropping systems (Anonymous, 2020). Currently, a major emphasis is being made on planning the nutrient management strategy based on the entire cropping system rather than focusing on individual crops because succeeding crops are influenced by inputs applied in preceding crops.

Complete reliance on chemical fertilizers not only leads to decline in productivity of the agroecosystems but also incurs high input cost on the farmers. Rather, the use of cheaper and non-harmful sources of nutrients like organic manures and biofertilizers along with chemical fertilizers will bring down the cost of nutrient application and will benefit
Department of Agronomy, Punjab Agricultural University, Ludhiana141 001, Punjab, India.

Corresponding Author: Rekha Ratanoo, Department of Agronomy, Punjab Agricultural University, Ludhiana-141 001, Punjab, India. Email: rekha.ratnoo@gmail.com

How to cite this article: Ratanoo, R., Walia, S.S., Saini, K.S. and Dheri, G.S. (2022). Residual Effects of Chemical Fertilizers, Organic Manure and Biofertilizers Applied to Preceding Gobhi sarson Crop on Summer Mung Bean (Vigna radiata L.). Legume Research. DOI: $10.18805 / L R-4767$.

Submitted: 09-08-2021 Accepted: 13-12-2021

Online: $14-01-2022$

the succeeding crops due to the carry-over effect. Jamval (2006) reported the increase in nutrient availability of the soil at the harvest of maize due to the application of FYM which positively influenced the yield of succeeding gobhi sarson and chickpea.

\section{MATERIALS AND METHODS}

An experiment was conducted at Students' research farm of Punjab Agricultural University, Ludhiana to study the residual effect of biofertilizers, chemical fertilizers and their combination with FYM on summer mung bean under gobhi sarson-summer mung bean system. Both the crops were grown in sequence in winter (rabi) and spring season, 
respectively in two cropping cycles during two consecutive years of 2016-17 and 2017-18. The experimental site is located in North-Western Indo-Gangetic plains. Latitude and longitude coordinates of Ludhiana are: $30.54^{\circ} \mathrm{N}, 75.50^{\circ} \mathrm{E}$, respectively. This region is characterized by sub-tropical and semi-arid climate. Soil at Ludhiana was loamy sand, medium in organic carbon $(0.43 \%)$, low in available nitrogen (231.5 $\left.\mathrm{kg} \mathrm{ha}^{-1}\right)$ and potassium (132.7 $\left.\mathrm{kg} \mathrm{ha}^{-1}\right)$ and high in available phosphorus $\left(23.8 \mathrm{~kg} \mathrm{ha}^{-1}\right)$. The $\mathrm{pH}$ and EC of the soil were 7.74 and $0.22 \mathrm{dS} \mathrm{m}^{-1}$, respectively.

The experiment was laid out in split plot design where chemical fertilizers and FYM were applied as main plot treatments and biofertilizers as sub plot treatments to the gobhi sarson crop. The main plot treatments included $\mathrm{CF}_{0}$ control i.e. no chemical fertilizers, $C_{1}-50 \%$ RDF (recommended dose of chemical fertilizers), $\mathrm{CF}_{2}-75 \% \mathrm{RDF}$, $\mathrm{CF}_{3}-100 \%$ RDF and $\mathrm{CF}_{4}-50 \%$ RDF + FYM @ $10 \mathrm{t} \mathrm{ha}^{-1}$. The recommended dose of fertilizers (RDF) was based on the soil test done for experimental area. The chemical fertilizers applied were nitrogen in the form of urea, phosphorous in the form of single super phosphate and potassium in the form of muriate of potash. The rate of recommended $\mathrm{N}, \mathrm{P}_{2} \mathrm{O}_{5}$ and $\mathrm{K}_{2} \mathrm{O}$ in gobhi sarson was 100 , 30 and $15 \mathrm{~kg} \mathrm{ha}^{-1}$, respectively and for summer mung bean was $12.5 \mathrm{~kg} \mathrm{ha}^{-1} \mathrm{~N}$ and $40 \mathrm{~kg} \mathrm{ha}^{-1} \mathrm{P}_{2} \mathrm{O}_{5}$. Half of the nitrogen, entire dose of phosphorous and potash was applied before sowing and rest of the half of the nitrogen was applied at first irrigation in gobhi sarson. FYM was applied 15 days before sowing in pre marked plots. The sub plot treatments included $\mathrm{BF}_{0}-$ no inoculation, $\mathrm{BF}_{1}-$ Azotobacter, $\mathrm{BF}_{2}-\mathrm{PSB}$, $\mathrm{BF}_{3}-$ Azotobacter + $\mathrm{PSB}$ and $\mathrm{BF}_{4}$ - consortium. Consortium is formulated containing Azotobacter, PSB and plant growth promoting rhizobacteria (PGPR). Biofertilizers were applied as seed treatment of gobhi sarson before sowing at the rate of $500 \mathrm{~g} \mathrm{ha}^{-1}$ (carrier based formulation containing $2 \times 10^{8}$ $\mathrm{cfu} / \mathrm{g})$. Succeeding summer mung bean was sown on the same plots after the harvest of gobhi sarson. The chemical fertilizers to summer mung bean were applied uniformly to the entire crop before sowing at recommended rate. The varieties used were "GSC7" of gobhi sarson and "SML832" of summer mung bean.

Observations on growth parameters, yield attributes and yield were taken in summer mung bean. Average data of five tagged plants from each plot were used for evaluating plant height, number of branches per plant, number of seeds per pod and 100-seed weight. Seed yield and biological yield were calculated from net plot area and converted into yield per hectare before subjecting to statistical analysis.

The data on each parameter were statistically analysed using technique of analysis of variance following the basic principles as explained by Cochran and Cox (1967) and adapted by Cheema and Singh (1991) in statistical package CPCS-I, software developed by Department of Mathematics, Statistics and Physics, PAU, Ludhiana. The treatment means were compared using ' $F$ ' test at $5 \%$ level of significance using least significant difference method.

\section{RESULTS AND DISCUSSION}

\section{Growth parameters and yield attributes}

The data regarding growth parameters and yield attributes of summer mung bean viz- plant height and dry matter accumulation at maturity, number of branches per plant, number of pods per plant and 100 seed weight were significantly affected by treatments applied to preceding crop. The maximum plant height was recorded with $50 \%$ RDF + FYM @ 10 t ha ${ }^{-1}\left(\mathrm{CF}_{4}\right)$ which was also significantly superior to all other doses of chemical fertilizers (Table 1).

Table 1: Residual effect of chemical fertilizers, FYM and biofertilizers on growth parameters of summer mung bean.

\begin{tabular}{|c|c|c|c|c|c|c|c|}
\hline \multirow{2}{*}{$\begin{array}{l}\text { Treatment } \\
\text { no. }\end{array}$} & \multirow[t]{2}{*}{ Treatments } & \multicolumn{2}{|c|}{$\begin{array}{l}\text { Plant height } \\
(\mathrm{cm})\end{array}$} & \multicolumn{2}{|c|}{$\begin{array}{l}\text { Dry matter accumulation } \\
\qquad\left(\mathrm{kg} \mathrm{ha}^{-1}\right)\end{array}$} & \multicolumn{2}{|c|}{$\begin{array}{c}\text { Number of branches } \\
\text { per plant }\end{array}$} \\
\hline & & 2017 & 2018 & 2017 & 2018 & 2017 & 2018 \\
\hline & Chemical fertilizers & & & & & & \\
\hline $\mathrm{CF}_{0}$ & Control (0\% RDF) & 41.8 & 51.0 & 2601 & 2815 & 2.77 & 4.37 \\
\hline $\mathrm{CF}_{1}$ & $50 \%$ RDF & 48.2 & 53.1 & 3310 & 3904 & 4.31 & 5.65 \\
\hline $\mathrm{CF}_{2}$ & $75 \%$ RDF & 51.1 & 55.6 & 3618 & 4204 & 5.28 & 6.91 \\
\hline $\mathrm{CF}_{3}$ & $100 \%$ RDF & 55.0 & 57.6 & 3731 & 4311 & 5.75 & 7.77 \\
\hline \multirow[t]{4}{*}{$\mathrm{CF}_{4}$} & $50 \%$ RDF + FYM @ 10 t ha $^{-1}$ & 60.5 & 61.9 & 4124 & 4688 & 6.83 & 9.39 \\
\hline & SEm \pm & 1.5 & 0.63 & 71 & 83 & 0.17 & 0.37 \\
\hline & $C D(p=0.05)$ & 5.0 & 2.1 & 233 & 271 & 0.55 & 1.22 \\
\hline & Biofertilizers & & & & & & \\
\hline $\mathrm{BF}_{0}$ & Control (No biofertilizers) & 47.9 & 53.5 & 3414 & 3865 & 4.48 & 6.17 \\
\hline $\mathrm{BF}_{1}$ & Azotobacter & 50.3 & 54.9 & 3451 & 3919 & 4.81 & 6.65 \\
\hline $\mathrm{BF}_{2}$ & PSB & 50.9 & 54.9 & 3464 & 3952 & 4.87 & 6.76 \\
\hline $\mathrm{BF}_{3}$ & Azotobacter + PSB & 53.2 & 57.5 & 3506 & 4074 & 5.35 & 7.07 \\
\hline \multirow[t]{3}{*}{$\mathrm{BF}_{4}$} & Consortium & 54.3 & 58.4 & 3550 & 4112 & 5.44 & 7.45 \\
\hline & SEm \pm & 1.3 & 0.61 & 19 & 32 & 0.17 & 0.21 \\
\hline & $C D(p=0.05)$ & 3.7 & 1.7 & 54 & 92 & 0.49 & 0.59 \\
\hline
\end{tabular}


Plant height varied from $41.8 \mathrm{~cm}$ and $51.0 \mathrm{~cm}$ in $\mathrm{CF}_{0}$ to 60.5 and $61.9 \mathrm{~cm}$ in $\mathrm{CF}_{4}$ during year 2017 and 2018, respectively. Kumpawat (2010) reported significantly higher plant height in mustard at applying $50 \%$ RDF + FYM as compared to $100 \%$ RDF alone to previous crop of black gram. Among different biofertilizers $\mathrm{BF}_{3}$ and $\mathrm{BF}_{4}$ gave significantly higher plant height than single inoculation $\left(\mathrm{BF}_{1}\right.$ and $\left.\mathrm{BF}_{2}\right)$ and no inoculation $\left(\mathrm{BF}_{0}\right)$ treatments.

Dry matter accumulation was significantly higher when $50 \%$ RDF + FYM @ $10 \mathrm{t} \mathrm{ha}^{-1}\left(\mathrm{CF}_{4}\right)$ was applied than all other treatments $\left(\mathrm{CF}_{0}, \mathrm{CF}_{1}, \mathrm{CF}_{2}\right.$ and $\left.\mathrm{CF}_{3}\right)$ (Table 2). This treatment had $9.6 \%$ more dry matter accumulation on an average during both the years as compared to $100 \%$ RDF $\left(\mathrm{CF}_{3}\right)$. The residual effect of FYM applied to previous crop of oats on succeeding sorghum crop was also reported by Devi et al., 2015. Residual effect of consortium $\left(\mathrm{BF}_{4}\right)$ on dry matter accumulation was maximum and significantly superior to single $\left(\mathrm{BF}_{1}\right.$ and $\mathrm{BF}_{2}$ ) and no inoculation $\left(\mathrm{BF}_{0}\right)$ whereas statistically at par with Azotobacter + PSB $\left(\mathrm{BF}_{3}\right)$. However, single inoculation treatments were numerically better than no inoculation treatment in producing dry matter content of the crop. These findings were similar to those of Deshwal et al., 2006 and Devi et al., 2015.

Number of branches per plant was higher by $127.2 \%$ and $89.4 \% \%$ in $\mathrm{CF}_{4}$ treatment as compared to control $\left(\mathrm{CF}_{0}\right)$ and $100 \% \operatorname{RDF}\left(\mathrm{CF}_{3}\right)$, respectively (Table 1$)$. Combined application of Azotobacter + PSB $\left(\mathrm{BF}_{3}\right)$ and consortium $\left(\mathrm{BF}_{4}\right)$ produced $16.8 \%$ and $21.2 \%$ more number of branches per plant respectively as compared to control,.

Number of pods per plant were also significantly influenced by different chemical fertilizer doses with $\mathrm{CF}_{4}$ being significantly superior to all other treatments and it varied from 12.16 to 25.39 in 2017 and 15.62 to 25.39 in
2018 (Table 2). Among different sub plot treatments i.e. biofertilizers, consortium application produced maximum number of pods per plant which was statistically at par with Azotobacter + PSB and significantly superior to all other treatments. Similarly, number of seeds per pod were significantly increased with application of FYM along with $50 \%$ RDF $\left(\mathrm{CF}_{4}\right)$ as compared to all other main plot treatments (Table 2). Number of seeds per pod varied from 9.12 and 9.51 in no biofertilizer $\left(\mathrm{BF}_{0}\right)$ treatment to 9.58 and 10.12 in consortium treatment $\left(\mathrm{BF}_{4}\right)$ during 2017 and 2018, respectively. 100-seed weight was maximum (i.e. $5.3 \mathrm{~g}$ ) in $\mathrm{CF}_{4}$ treatment and it was significantly superior to all other treatments (Table 2). Application of consortium i.e. $\mathrm{BF}_{4}$ produced maximum 100 seed weight among different biofertilizers' treatments. Davari et al. (2012) reported significant and positive residual effect of FYM and biofertilizers applied to previous crop of rice and wheat on succeeding summer mung bean in terms of yield attributes i.e. number of pods per plant, number of seeds per pod and test weight.

\section{Seed and biological yield}

The maximum seed yield (962 kg ha-1 and $1068 \mathrm{~kg} \mathrm{ha}^{-1}$ ) and biological yield (4590 kg ha-1 and $5101 \mathrm{~kg} \mathrm{ha}^{-1}$ ) of summer mung bean was observed through integrated use of $50 \%$ RDF + FYM@ 10 t ha $^{-1}$ followed by $100 \%$ RDF, $75 \%$ RDF, 50\% RDF and control, respectively (Table 3). Effect of FYM applied to rice/soyabean on succeeding summer mung bean growth and yield has also been reported by Suryantini (2016). FYM application in oat crop increased dry matter yield and green fodder yield of succeeding sorghum crop due to the improvement in soil physical and chemical properties and slow releasing of nutrients for long duration (Devi et al. 2015). Incontrast, Shivran and Giri (2006) reported significantly

Table 2: Residual effect of chemical fertilizers, FYM and biofertilizers on yield attributes of summer mung bean.

\begin{tabular}{|c|c|c|c|c|c|c|c|}
\hline \multirow{2}{*}{$\begin{array}{l}\text { Treatment } \\
\text { no. }\end{array}$} & \multirow[t]{2}{*}{ Treatments } & \multicolumn{2}{|c|}{$\begin{array}{c}\text { Number of pods } \\
\text { per plant }\end{array}$} & \multicolumn{2}{|c|}{$\begin{array}{l}\text { Number of seeds } \\
\text { per pod }\end{array}$} & \multicolumn{2}{|c|}{$\begin{array}{l}100 \text {-seed } \\
\text { weight }(\mathrm{g})\end{array}$} \\
\hline & & 2017 & 2018 & 2017 & 2018 & 2017 & 2018 \\
\hline & Chemical fertilizers & & & & & & \\
\hline $\mathrm{CF}_{0}$ & Control (0\% RDF) & 13.79 & 17.14 & 8.94 & 10.00 & 5.06 & 5.12 \\
\hline $\mathrm{CF}_{1}$ & $50 \%$ RDF & 19.35 & 20.55 & 9.87 & 10.67 & 5.17 & 5.22 \\
\hline $\mathrm{CF}_{2}$ & $75 \%$ RDF & 21.45 & 22.87 & 10.34 & 10.87 & 5.19 & 5.25 \\
\hline $\mathrm{CF}_{3}$ & $100 \%$ RDF & 22.79 & 23.62 & 10.55 & 11.10 & 5.21 & 5.26 \\
\hline \multirow[t]{4}{*}{$\mathrm{CF}_{4}$} & $50 \%$ RDF + FYM @ 10 t ha $^{-1}$ & 25.04 & 26.23 & 11.14 & 11.82 & 5.29 & 5.32 \\
\hline & SEm \pm & 0.65 & 0.74 & 0.16 & 0.20 & 0.02 & 0.01 \\
\hline & $C D(p=0.05)$ & 2.11 & 2.43 & 0.50 & 0.66 & 0.08 & 0.04 \\
\hline & Biofertilizers & & & & & & \\
\hline $\mathrm{BF}_{0}$ & Control (No biofertilizers) & 19.97 & 21.39 & 9.84 & 10.31 & 5.11 & 5.17 \\
\hline $\mathrm{BF}_{1}$ & Azotobacter & 20.12 & 21.65 & 9.96 & 10.66 & 5.15 & 5.19 \\
\hline $\mathrm{BF}_{2}$ & PSB & 20.44 & 21.88 & 10.10 & 10.79 & 5.15 & 5.22 \\
\hline $\mathrm{BF}_{3}$ & Azotobacter + PSB & 20.78 & 22.50 & 10.40 & 11.23 & 5.23 & 5.28 \\
\hline \multirow[t]{3}{*}{$\mathrm{BF}_{4}$} & Consortium & 21.10 & 22.99 & 10.53 & 11.47 & 5.29 & 5.30 \\
\hline & SEm \pm & 0.21 & 0.18 & 0.10 & 0.17 & 0.02 & 0.01 \\
\hline & $C D(p=0.05)$ & 0.63 & 0.52 & 0.28 & 0.50 & 0.06 & 0.04 \\
\hline
\end{tabular}


Residual Effects of Chemical Fertilizers, Organic Manure and Biofertilizers Applied to Preceding Gobhi sarson Crop on Summer...

Table 3: Residual effect of chemical fertilizers, FYM and biofertilizers on yield $\left(\mathrm{kg} \mathrm{ha}^{-1}\right)$ of summer moong bean.

\begin{tabular}{|c|c|c|c|c|c|}
\hline \multirow{2}{*}{$\begin{array}{l}\text { Treatment } \\
\text { no. }\end{array}$} & \multirow[t]{2}{*}{ Treatments } & \multicolumn{2}{|c|}{$\begin{array}{l}\text { Seed yield } \\
\left(\mathrm{kg} \mathrm{ha}^{-1}\right)\end{array}$} & \multicolumn{2}{|c|}{$\begin{array}{c}\text { Biological yield } \\
\left(\mathrm{kg} \mathrm{ha}^{-1}\right)\end{array}$} \\
\hline & & 2017 & 2018 & 2017 & 2018 \\
\hline & Chemical fertilizers & & & & \\
\hline $\mathrm{CF}_{0}$ & Control (0\% RDF) & 665 & 695 & 2916 & 3298 \\
\hline $\mathrm{CF}_{1}$ & $50 \%$ RDF & 779 & 845 & 3713 & 4125 \\
\hline $\mathrm{CF}_{2}$ & $75 \%$ RDF & 840 & 914 & 4020 & 4445 \\
\hline $\mathrm{CF}_{3}$ & $100 \%$ RDF & 889 & 964 & 4179 & 4667 \\
\hline \multirow[t]{4}{*}{$\mathrm{CF}_{4}$} & $50 \%$ RDF + FYM @ 10 t ha $^{-1}$ & 962 & 1068 & 4590 & 5101 \\
\hline & SEm \pm & 16 & 17 & 67 & 71 \\
\hline & $C D(p=0.05)$ & 52 & 57 & 220 & 230 \\
\hline & Biofertilizers & & & & \\
\hline $\mathrm{BF}_{0}$ & Control (No biofertilizers) & 812 & 878 & 3790 & 4169 \\
\hline $\mathrm{BF}_{1}$ & Azotobacter & 820 & 891 & 3830 & 4258 \\
\hline $\mathrm{BF}_{2}$ & PSB & 825 & 897 & 3873 & 4312 \\
\hline $\mathrm{BF}_{3}$ & Azotobacter + PSB & 833 & 902 & 3910 & 4402 \\
\hline \multirow[t]{3}{*}{$\mathrm{BF}_{4}$} & Consortium & 845 & 918 & 4013 & 4495 \\
\hline & SEm \pm & 7 & 7 & 34 & 53 \\
\hline & $C D(p=0.05)$ & 19 & 21 & 97 & 150 \\
\hline
\end{tabular}

higher grain and stalk yield of pigeonpea with residual effect of $100 \%$ RDF as compared to $50 \%$ RDF and control.

Among different biofertilizers treatments, the maximum seed and biological yield was recorded with consortium application $\left(\mathrm{BF}_{4}\right)$ followed by Azotobacter $+\mathrm{PSB}\left(\mathrm{BF}_{3}\right)$. Both of these treatments were significantly superior to single inoculation $\left(\mathrm{BF}_{1}\right.$ and $\left.\mathrm{BF}_{2}\right)$ and no inoculation $\left(\mathrm{BF}_{0}\right)$ treatments but statistically at par with each other. However, increase in seed yield varied from 1.05 to $3.43 \%$ in single inoculation treatments $\left(\mathrm{BF}_{1}\right.$ and $\left.\mathrm{BF}_{2}\right)$ as compared to no inoculation $\left(B F_{0}\right)$ across both the years. There were no significant interactions between main plot and sub-plot treatments in terms of performance of summer mung bean. PSB and Azotobacter positively affect mung bean growth and yield (Walpola and Yoon, 2013; Venkatarao et al., 2017; Peter and Satish, 2015; Rani et al., 2016).

\section{CONCLUSION}

From the analysis of two years of experimental trial, it can be concluded that integrated use of FYM and chemical fertilizers in gobhi sarson had significantly higher carry-over effect on succeeding summer mung bean growth and yield. Among different biofertilizers treatments, application of consortium which included all the three bioinoculants i.e. Azotobacter, PSB and PGPR had best residual effect on growth and yield of summer mung bean.

\section{REFERENCES}

Anonymous, (2020). Package of Practices for Crops of Punjab: Rabi 2020-21. Punjab Agricultural University, Ludhiana. 37: 110-13.

Cheema, H.S. and Singh, B. (1991). Software Statistical Package CPCS-I. Department of Mathematics, Statistics and Physics, Punjab Agricultural University, Ludhiana, India.
Cochran, W.G. and Cox, G.M. (1967). Experimental Designs. Asia Publication House, New Delhi.

Davari, M., Sharma, S.N. and Mirzakhani, M. (2012). Residual influence of organic materials, crop residues and biofertilizerson performance of succeeding mung bean in an organic ricebased cropping system. International Journal of Recycling of Organic Waste in Agriculture. 1: 14-22.

Deshwal, V.K., Kumar, T., Dubey, R.C. and Maheshwari, D.K. (2006). Long-term effect of Pseudomonas aeruginosa GRC1 on yield of subsequent crops of paddy after mustard seed bacterization. Current Science. 91: 423-24.

Devi, U., Singh, K., Kumar, S. and Kumar, P. (2015). Residual effect of nitrogen levels, organic manures and Azotobacter inoculation in multi-cut oats on succeeding sorghum crop. Forage Research. 40: 254-56.

Jamval, J.S. (2006). Effect of integrated nutrient management in maize (Zea mays) on succeeding winter crops under rainfed conditions. Indian Journal of Agronomy. 51: 14-16.

Jat, H.S., Jat, M.L., Sharma, P.C., Sidhu, H.S., McDonald, A.J. (2016). Sustainable Intensification of Cereal Based Systems in Semi-arid North West India-climate and Non-climate Drivers of Change. In: Natural Resource Management in Arid and Semi-arid Ecosystems for Climate Resilient Agriculture. [Pareek, N.K. and Arora, S. (eds.)]. Soil Conservation Society of India, New Delhi. pp. 1-11.

Kumpawat, B.S. (2010). Integrated nutrient management in blackgram (Vigna mungo) and its residual effect on succeeding Imustard (Brassica juncea) crop. Indian Journal of Agricultural Sciences. 80: 76-79.

Peter, F. and Satish, A.B. (2015). Effect of biofertilizer on the growth of mungbean [Vigna radiata (L.) Wilczek]. International Research Journal of Science and Engineering. 3: 51-54.

Prasad, R. (2005). Rice-wheat cropping system. Advances in Agronomy. 86: 285-339. 
Rani, M., Prakash, V. and Khan, K. (2016). Response of mungbean [Vigna radiata (L.) Wilczek] to phosphorus, sulphur and PSB during summer season. Agricultural Science Digest. 36: $146-48$.

Shivran, R.K. and Giri, G. (2006.) Effect of integrated nutrient management on productivity, quality and nutrient uptake by Indian mustard and their residual effect on pigeonpea. Annals of Agricultural Research New Series 27: 339-41.

Suryantini, (2016). Effect of phosphorus, organic and biological fertilizer on yield of mungbean (Vigna radiata) under two cropping patterns. Nusantara Bioscience. 8: 273-77.
Venkatarao, C.V., Naga, S.R., Yadav, B.L., Koli, D.K. and Rao, I.J. (2017). Effect of phosphorus and biofertilizers on growth and yield of mungbean [Vigna radiata (L.) Wilczek]. International Journal of Current Microbiology and Applied Sciences. 6: 3992-97.

Walpola, B.C. and Yoon, M.H. (2013). Phosphate solubilizing bacteria: Assessment of their effect on growth promotion and phosphorous uptake of mung bean [Vigna radiata (L.) R. Wilczek]. Chilean Journal of Agricultural Research. 73: 275-81. 